\title{
Vascular Endothelial Growth Factor Insertion/Deletion gene polymorphism in patients with type 2 diabetes and diabetic peripheral polyneuropathy
}

\section{Polimorfismului Inserție/Deleție al genei Factorului de Creștere Endotelial Vascular la pacienții cu diabet zaharat tip 2 și polineuropatie diabetică periferică}

\author{
Adina Stoian ${ }^{1}$, Anca Bacârea ${ }^{1 *}$, Anca Moţăţăianu², Mircea Stoian³, Florina \\ Gliga $^{1}$, Vladimir Bacârea ${ }^{4}$, Duicu Carmen ${ }^{5}$, Claudia Bănescu ${ }^{6}$ \\ University of Medicine and Pharmacy Tirgu Mures, \\ 1. Pathophysiology Department, 2. Neurology Department, \\ 3.Mures County Hospital, Intensive Care Unit Department, 4. Medical Research Methodology \\ Department, 5. Pediatrics Department, 6. Genetics Department
}

\begin{abstract}
The aim of this work was to study for the first time in Romania Insertion/Deletion (I/D) polymorphism of the Vascular Endothelial Growth Factor (VEGF) gene in a group of patients with established type 2 diabetes mellitus (DM) and diabetic peripheral neuropathy (DPN) compared with a control group.

This was a case-control study consisting of a group of 84 patients with type 2 DM and DPN, diagnosed by clinical neurological examination and electrophysiological nerve conduction studies and a control group of 90 healthy volunteers. For deoxyribonucleic acid (DNA) isolation, a DNA purification kit from Zymo Research was used. In vitro amplification of DNA sequences was achieved by polymerase chain reaction (PCR). Selective in vitro amplification of a DNA fragment of known sequence is based on the principle of extension of a primer ("primer and PCR amplicon"). DNA fragments were separated by gel electrophoresis. For proper viewing and interpreting of agarose gels Vilber Lourmat system was used. D allele frequency of VEGF was significantly higher in patients with diabetic peripheral neuropathy (53.57\%) compared with controls (25\%), $p=0.0001$.

There is a positive association between I/D polymorphism of VEGF gene and the presence of diabetic peripheral polyneuropathy. Our study suggests that D allele of VEGF gene is a risk factor for the occurrence of DPN.

Keywords: polyneuropathy, I/D polymorphism, VEGF gene, diabetes mellitus

Rezumat

Scopul acestei lucrări constă în studierea pentru prima dată în România a polimorfismului I/D al genei VEGF la un grup de pacienți cu diabet zaharat tip 2 și polineuropatie diabetică periferică comparativ cu un grup de control.

*Corresponding author: Anca Bacârea, University of Medicine and Pharmacy Tirgu Mures, Pathophysiology Department, e-mail: bacareaa@yahoo.com
\end{abstract}


Acesta este un studiu de tip caz-control constând din 84 de pacienți cu diabet zaharat tip 2 și polineuropatie diabetică periferică, diagnosticată prin examen clinic neurologic şi studii electrofiziologice de conducere nervoasă şi un grup de control alcătuit din 94 de voluntari sănătoşi. Pentru izolarea acidului dezoxiribonucleic s-a utilizat kitul ADN de la Zymo Research. Amplificarea in vitro a secvențelor de ADN a avut loc prin reacția de polimerizare în lanț. Amplificarea selectivă in vitro a unui fragment de ADN cu secvenţă cunoscută se realizează pe baza principiului extensiei unei amorse ("primer sau amplimer"). Fragmentele de ADN au fost separate prin electroforeză în gel. Vizualizarea și interpretarea gelurilor de agaroza s-a efectuat cu ajutorul sistemului de fotodocumentare de la Vilber Lourmat.

Frecvența alelei D a VEGF a fost semnificativ statistic mai mare la pacienţii cu neuropatie periferică diabetică (53.57\%) comparativ cu grupul de control (25\%).

Există o asociere pozitivă intre polimorfismul I/D al genei VEGF şi prezența polineuropatiei diabetice periferice. Studiul nostru sugerează că alela D a genei VEGF este un factor de risc pentru apariția polineuropatiei diabetice periferice.

Cuvinte cheie: polineuropatie, polimorfism I/D, gena VEGF, diabet zaharat

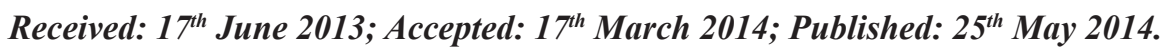

\section{Introduction}

Vascular factors and metabolic disorders are involved in etiopathogenesis of complications (such as diabetic neuropathy, nephropathy and retinopathy) that occurs in patients with a long-standing type 2 DM (1). Diabetic neuropathy is one of the most common microvascular complications of type 2 DM. Risk of developing diabetic neuropathy is proportional to the degree and duration of hyperglycemia (2).

The exact pathophysiologic mechanism is not fully known, but some metabolic imbalances have been suggested as underlying cause of microvascular damage, such as oxidative stress, accumulation of advanced glycation end products, and modification of extracellular proteins and alteration of their function (3). Patients may also have genetic characteristics that predispose for the occurrence of these complications (4).

VEGF is a family of growth factors with high specificity for endothelial cells, whose action is achieved through receptors of which VEGF1 and VEGF2 are best described. Under normal conditions, the expression of these receptors is reduced, but in case of tissue hypoxia overexpression of these receptors and increased VEGF occur. As a consequence proliferation and mi- gration of endothelial cells is promoted, leading to angiogenesis and development of collateral circulation in hypoxic tissues $(5,6)$. During the development of the peripheral nervous system, VEGF stimulates Schwann cell proliferation and axonal growth, promotes glial cells growth, neurogenesis and has a neuroprotective effect. Furthermore, there is evidence that VEGF guide neuronal migration in the embryonic brain and stimulates the growth of vascular and axonal epidermal network (7).

Factors such as DM, high cholesterol and age can alter VEGF expression in the heart and extremities. VEGF gene therapy or VEGF injections aimed to stimulate angiogenesis processes and prevention of ischemia-induced tissue necrosis $(6,8-10)$. Transfer of DNA encoding VEGF in animal experiments had promising results on peripheral nerves in case of Schwann cells hypoxia (11). However, VEGF hyperactivity appears to have adverse effects on the retina with proliferative retinopathy occurrence (11).

Given the ischemic nature of diabetic peripheral neuropathy and the need to restore circulation at microcirculation level (including vasa nervorum), VEGF is the subject of recent studies regarding microvascular complications of diabetes, including DPN (12-14). 
Studies have shown a progressive endothelial dysfunction, reduced VEGF expression and loss of intra-epidermal nerve fibers of the lower limbs of diabetic patients, proportionally with increasing severity of peripheral neuropathy (15).

\section{Aim of study}

The aim of the study was to investigate Insertion/Deletion (I/D) polymorphism of the VEGF gene in a group of patients with type $2 \mathrm{DM}$ and DPN compared with a control group. We sought to estimate allele frequencies of studied genes and to establish if there is any relation with the presence of DPN.

\section{Materials and methods}

The group of cases consists of 84 patients with type 2 DM, diagnosed with diabetic peripheral sensorimotor polyneuropathy based on neurological clinical examination and confirmed by electrophysiological studies performed in the Electrophysiology Laboratory of County Emergency Hospital Tirgu Mures (37 men and 47 women, mean age $59.41 \pm 8.68$ years). The control group consists of 90 healthy volunteers (50 men, 40 women, mean age 51.31 7.95 years). The study protocol was approved by the Ethics Committee of University of Medicine and Pharmacy Tirgu Mures and the study was conducted in accordance with the Helsinki Declaration, for a period of six months in 2011.

\section{Criteria for inclusion:}

- Patients with type 2 DM with diabetic sensorimotor polyneuropathy, diagnosed by clinical examination and confirmed by nerve conduction studies;

- Patients aged over 18 years;

\section{Exclusion criteria:}

Patients diagnosed with type 2 DM, detected with another causes of neuropathy (thyroid dysfunctions, cancer, renal failure, vitamin B12 deficiency, liver virus infection).

\section{Genotyping of polymorphism I/D VEGF gene}

Amplification of VEGF gene fragments of interest: DNA was extracted from peripheral venous blood using the Genomic DNA Purification Kit extraction kit from Zymo Research. For analysis of VEGF polymorphism I/D we used PCR (polymerase chain reaction) as previously described (16). The sequences of VEGF sense and antisense primers were: sense primer 5'-GCTGAGAGTGGGGCTGACTAGGTA-3' and antisense primer 5'-GTTTCTGACCTGGCTATTTCCAGG - 3', manufactured by Eurogentec.

VEGF reaction conditions for amplification were: initial denaturing at $95^{\circ} \mathrm{C}$ for 6 minutes resulting in a mixture of single-stranded fragments, followed by 35 cycles of reaction according to the following conditions: a distortion at $94^{\circ} \mathrm{C}$ for 1 minute, followed by hybridization primers (annealing) at $57^{\circ} \mathrm{C}$ to complementary sequences (located in position $3^{\circ}$ ) on each chain, for 1 minute and 30 seconds, followed by primary extension in which each primer is elongated (extended) in the sense 5' - 3 ', forming complementary strand of the copied sequence (matrix) at $72^{\circ} \mathrm{C}$ for 2 minutes and a final elongation for 10 minutes at $72^{\circ} \mathrm{C}$.

PCR-products were visualized by electrophoresis in 3\% agarose gel (MetaPhor from Lonza). For proper visualization we used ethidium bromide and images were captured with Vilber Lourmat system.

Statistical analysis was performed using GraphPad install 3 (GraphPad, San Diego, CA, USA). The p-value was calculated with Yates-corrected chi-square test and $p$ value of less than 0.05 was considered significant. According with study design OR (Odds Ratio) and 95\% CI (Confidence Intervals) were calculated. The tests used in inferential statistics were chisquare for $2 \times 2,2 \times 3,3 \times 3$ contingency tables for binary data and Kruskall Wallis test for compar- 
ing more than two variables (for variables with non-Gaussian distribution). For data collection we used MS Excel. Allele frequency was estimated by the gene counting method.

\section{Results}

Some general characteristics of patients group [such as BMI - body mass index, duration of diabetes, presence of different micro- and macrovascular complications band comorbidities, glycated hemoglobin (HbA1c)] and the characteristics of subgroups according to genotype are shown in Table I. Carriers of the three genotypes had similar characteristics, except the blood pressure $(p=0.04)$. Although not statistically significant, we can observe that the mean value of glycated hemoglobin is the smallest in II genotype diabetic patients.

The results regarding allele frequency and genotype polymorphism of I/D VEGF gene in patients with type 2 diabetes and in the control group are presented in Table II.
Thus, in patients group the most commonly encountered were ID genotype $(54.76 \%)$ and deletion/deletion (DD) genotype (26.19\%) compared with controls where the most commonly found genotypes were II $(57.78 \%)$ and ID (34.44\%). Regarding the distribution of alleles in the patients group the most frequently encountered was D allele (53.57\%) compared to the control group where I allele was more frequently found $(75 \%)$.

Analyzing the frequency of allele, VEGF D allele is observed to be significantly increased in patients with diabetic neuropathy compared with control group $(\mathrm{p}<0.0001$, chi-square test; OR = $3.462,95 \% \mathrm{CI}=2.199$ to 5.449 ). There is a positive, statistically significant relation between the presence of $\mathrm{D}$ allele and the occurrence of type 2 DM and DPN compared with allele I.

There is a positive, statistically significant relation between the presence of DD genotype and the occurrence of type $2 \mathrm{DM}$ and DPN compared with genotype II $(\mathrm{p}<0.0001 ; \mathrm{OR}=10.214,95 \%$ $\mathrm{CI}=3.688$ to 28.291$)$.

Table I. General characteristics of patients with diabetes and comparison of patients according to genotype

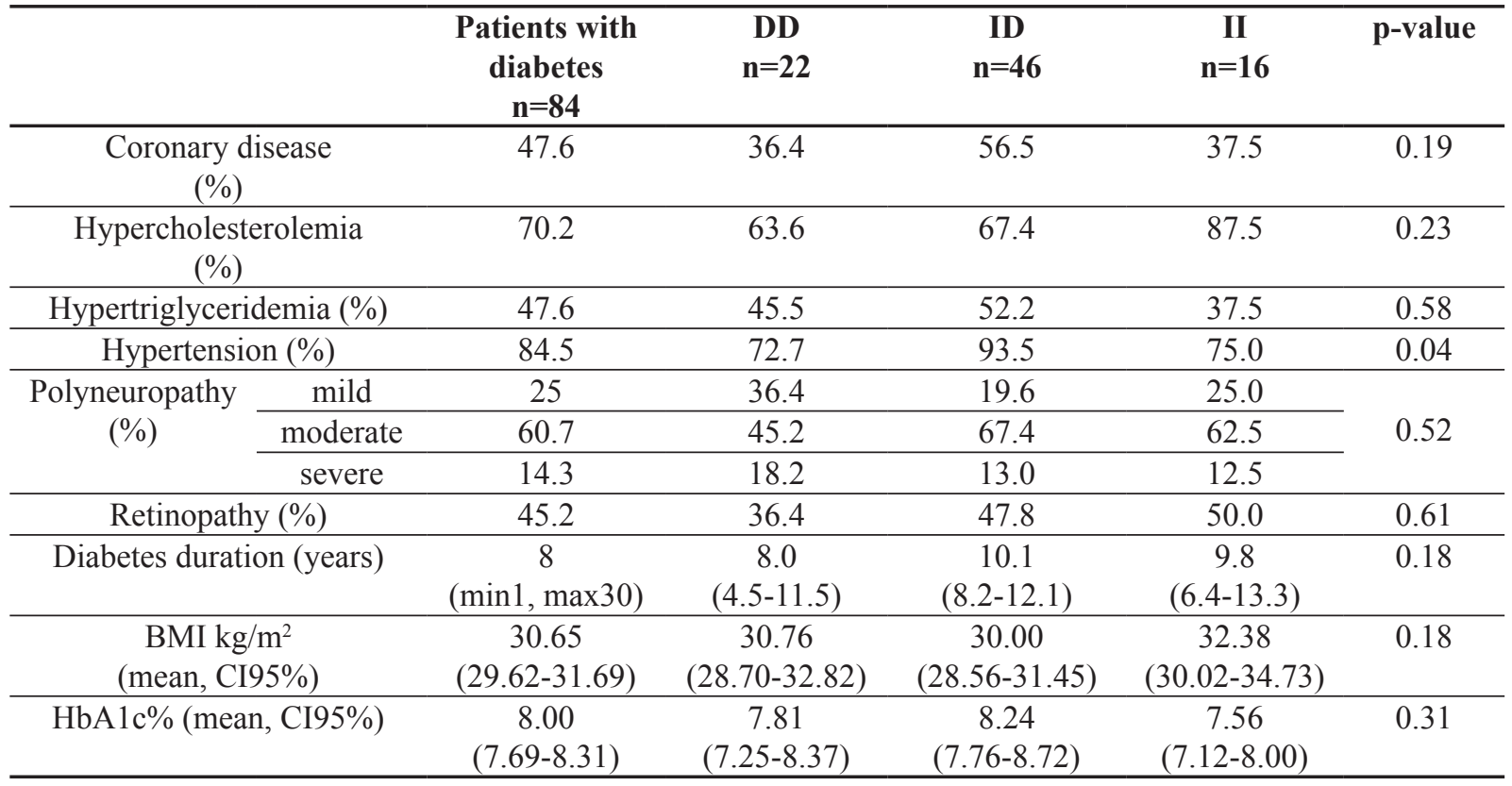


Table II. Allele frequency and genotype of VEGF gene polymorphism in patients with type 2 DM and DPN and in the control group

\begin{tabular}{|c|c|c|c|}
\hline Variable & $\begin{array}{c}\begin{array}{c}\text { Case group } \\
\mathrm{n}=84\end{array} \\
\end{array}$ & $\begin{array}{c}\text { Control group } \\
\mathrm{n}=90\end{array}$ & p-value \\
\hline \multicolumn{4}{|c|}{ Genotype } \\
\hline II & $16(19.05 \%)$ & $52(57.78 \%)$ & 0.0001 \\
\hline ID & $46(54.76 \%)$ & $31(34.44 \%)$ & 0.005 \\
\hline $\mathrm{DD}$ & $22(26.19 \%)$ & $7(7.78 \%)$ & 0.0001 \\
\hline \multicolumn{4}{|c|}{ Allele } \\
\hline I & $78(46.43 \%)$ & $135(75 \%)$ & 0.0001 \\
\hline $\mathrm{D}$ & $90(53.57 \%)$ & $45(25 \%)$ & 0.0001 \\
\hline
\end{tabular}

There is a positive, statistically significant relation between ID genotype and occurrence of type $2 \mathrm{DM}$ and DPN compared with genotype II $(\mathrm{p}<0.0001 ; \mathrm{OR}=4.823 ; 95 \% \mathrm{CI}=2.342-$ 9.930).

Homozygous II genotype was more frequent in the control group versus ID + DD genotypes that were more frequent in patients with DPN ( $\mathrm{p}<0.0001 ; \mathrm{OR}=5.816,95 \% \mathrm{CI}=2.926$ to 11.559). There is a positive, statistically significant relation between genotypes ID + DD and occurrence of type 2 DM and DPN compared with genotype II.
In figure 1, I/D VEGF gene the polymorphism can be observed in some patients included in the study.

\section{Discussions}

The human VEGF gene is located on the short arm of chromosome $6(6 \mathrm{p} 21.3)$ and is highly polymorphic $(16,17)$. One polymorphism is the insertion/deletion (I/D) of a $18 \mathrm{bp}$ fragment in -2549 position of the promoter region and demonstrated its involvement in the development of many diseases, especially those that are based on angiogenesis $(16,18)$.

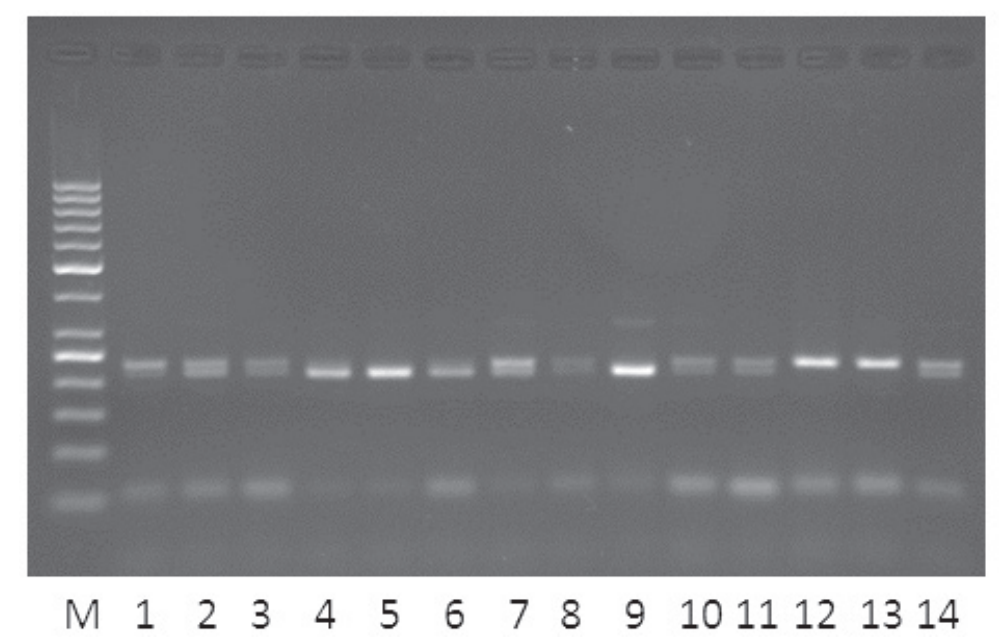

Figure 1. I/D VEGF gene polymorphism (ID - heterozygote, DD - homozygote for D allele; M - molecular weight marker 50 base pairs) 2, 3, 7, 8, 10, 11, 14 - genotype ID; 4, 5, 9 - DD genotype; 1, 12, 13 - genotype II. I allele corresponds to a fragment of 229 base pairs, and D allele to a fragment of 211 base pairs. We notice the presence of homozygous II and DD, respectively the presence heterozygote ID. 
In the pathogenesis of DPN appears a loss of vasa nervorum inducing tissue hypoxia with secondary increase of VEGF activity in order to induce angiogenesis. Intramuscular VEGF gene transfer seemed to improve neuropathic symptoms in diabetic patients but there are side effects of VEGF in retina (19). There are studies showing that there is an increased serum VEGF level in patients with DPN compared with those with diabetes mellitus without DPN (20).

We have not found published data in the literature about the existence of studies on the influence of I/D VEGF gene polymorphism in the development of DPN. Ours seems to be the first study of its kind. The role of I/D VEGF gene polymorphism in the pathogenesis of DPN is unclear due to lack of data reported in the literature. There are reports of other VEGF gene polymorphisms and DPN and reports on the influence of I/D VEGF gene polymorphism in the development of diabetic retinopathy and diabetic nephropathy. Thus, D allele of I/D VEGF gene polymorphism was reported as an independent risk factor in the development of diabetic retinopathy (17) and Young et al showed that DD genotype is significantly increased in patients with diabetic nephropathy compared with those without this microvascular complication of diabetes (40.2\% versus $22.7 \%$ ) (21). In our patient group, the frequency of microvascular complication such as retinopathy was similar to that reported by another Romanian study performed on patients with type 2 DM (22). The BMI (Body mass index) of our DPN patients was higher than the BMI of the diabetes hemodialysis patients reported by Moldovan et al (23). The difference can be explained by vascular complications and comorbidities of the patients included in the studies mention above. Coronary disease was found in $47.6 \%$ of our patients, which is similar to that observed in a recent study, in which thirteen of the patients from twenty-six $(50 \%)$ had coronary artery disease (22).
Assuming that there is an influence of $\mathrm{I} / \mathrm{D}$ VEGF gene polymorphism in the pathogenesis of DM, we proved that there is a statistically significant association between DD genotype and presence of DPN. According to our results, type II VEGF genotype was more frequent in the control group which may suggest a possible protective role of this genotype in the development of DM and DPN. ID + DD genotypes were more common in patients with diabetic neuropathy and their presence may be a risk factor for the development of type $2 \mathrm{DM}$ and DPN.

I allele may have a protective role, being more common in the control group compared to the $\mathrm{D}$ allele. $\mathrm{D}$ allele has been reported by other studies to be associated with the development of diabetic retinopathy and nephropathy. Our results support the assumption that the presence of the $\mathrm{D}$ allele is associated with increased risk of microvascular complications in DM, including diabetic neuropathy, being an independent risk factor for diabetic neuropathy.

Certain limitations of this study should be mentioned. We included a relatively small number of cases with DPN and we did not have a group of patients with DM free of DPN. Expanding research on larger groups of patients and a new group of DM without DPN could provide additional data regarding the role of I/D VEGF gene polymorphism in the development of DPN in patients with type $2 \mathrm{DM}$. We haven't studied the correlation between VEGF levels and gene polymorphism. This would be an interesting subject to study in further investigations and we intend to do so.

\section{Conclusions}

Our results showed that I/D VEGF gene polymorphism in the promoter region is associated with DPN. D allele of the VEGF polymorphism could be an independent risk factor of diabetic neuropathy. 


\author{
Abbreviations list \\ I/D - Insertion/Deletion \\ D/D - Deletion/Deletion \\ VEGF - Vascular Endothelial Growth Factor \\ DM - diabetes mellitus \\ DPN - diabetic peripheral neuropathy \\ DNA - deoxyribonucleic acid \\ PCR - polymerase chain reaction \\ BMI - body mass index \\ CI - Confidence Intervals \\ OR - Odds Ratio \\ HbA1c - glycated hemoglobin
}

\section{Author Disclosure Statement}

The authors state that they have no conflict of interest.

\section{References}

1. Potra RA, Kacso MI, Bondor CI, Gherman-Căprioară M. The predictive value of serum intercellular adhesion molecule 1 for the progression of diabetic kidney disease in type 2 diabetic patients. Rev Romana Med Lab. 2013;21(4):399-406. DOI: 10.2478/rrlm-2013-0045

2. Michael J. Fowler Microvascular and Macrovascular Complications of Diabetes. Clinical Diabetes. 2008;26(2):77-82. DOI: 10.2337/diaclin.26.2.77

3. Pradeepa R, Anjana RM, Unnikrishnan R, Ganesan A, Mohan V, Rema M. Risk factors for microvascular complications of diabetes among South Indian subjects with type 2 diabetes-the Chennai Urban Rural Epidemiology Study (CURES) Eye Study-5. Diabetes Technol Ther. 2010;12(10):755-61. DOI: 10.1089/dia.2010.0069

4. Abbott CA, Chaturvedi N, Malik RA, Salgami E, Yates AP, Pemberton PW, et al. Explanations for the lower rates of diabetic neuropathy in Indian Asians Versus Europeans. Diabetes Care. 2010;33(6):1325-30. DOI: $10.2337 / \mathrm{dc} 09-2067$

5. Shweiki D, Itin A, Soffer D, Keshet E. Vascular endothelial growth factor induced by hypoxia may mediate hypoxia-initiated angiogenesis. Nature. 1992;359:8435. DOI: $10.1038 / 359843 \mathrm{a} 0$

6. Zhang X, Bao S, Hambly BD, Gillies MC. Vascular endothelial growth factor-A: a multifunctional molecular player in diabetic retinopathy. Int J Biochem Cell Biol. 2009;41(12):2368-71. DOI: 10.1016/j.biocel.2009.07.011

7. Rosenstein JM, Krum JM, Ruhrberg C. VEGF in the nervous system. Organogenesis. 2010;6(2):107-14.
DOI: 10.4161/org.6.2.11687

8. Ropper AH, Gorson KC, Gooch CL, Weinberg DH, Pieczek A, Ware JH, et al. Vascular endothelial growth factor gene transfer for diabetic polyneuropathy: a randomized, double-blinded trial. Ann Neurol. 2009;65(4):386-93. DOI: 10.1002/ana.21675

9. Isner JM. Tissue responses to ischemia: local and remote responses for preserving perfusion of ischemic muscle. J Clin Invest. 2000;106:615-9. DOI: 10.1172/ JCI10961

10. Giacca M, Zacchigna S. VEGF gene therapy: therapeutic angiogenesis in the clinic and beyond. Gene Ther. 2012;19(6):622-9. DOI: 10.1038/gt.2012.17

11. Duh E, Aiello LP. Vascular endothelial growth factor and diabetes: the agonist versus antagonist paradox. Diabetes. 1999; 48:1899-906. DOI: 10.2337/diabetes.48.10.1899

12. Aiello LP, Wong JS. Role of vascular endothelial growth factor in diabetic vascular complications. Kidney Int Suppl. 2000;77:S113-9. DOI: 10.1046/j.15231755.2000.07718.x

13. Leinninger GM, Vincent AM, Feldman EL. The role of growth factors in diabetic peripheral neuropathy. J Peripher Nerv Syst. 2004;9:26-53. DOI: 10.1111/j.10859489.2004.09105.x

14. Tavakkoly-Bazzaz J, Amoli MM, Pravica V, Chandrasecaran R, Boulton AJ, Larijani B, et al. VEGF gene polymorphism association with diabetic neuropathy. Mol Biol Rep. 2010;37:3625-30. DOI: 10.1007/ s11033-010-0013-6

15. Quattrini C, Jeziorska M, Boulton AJ, Malik RA. Reduced vascular endothelial growth factor expression and intra-epidermal nerve fiber loss in human diabetic neuropathy. Diabetes Care. 2008;31(1):140-5. DOI: $10.2337 / \mathrm{dc} 07-1556$

16. Buraczynska M, Ksiazek P, Baranowicz-Gaszczyk I, Jozwiak L. Association of the VEGF gene polymorphism with diabetic retinopathy in type 2 diabetic patients. Nephrol Dial Transplant. 2007;22(3):827-32. DOI: $10.1093 / \mathrm{ndt} / \mathrm{gfl} 641$

17. Stevens A, Soden J, Brenchley PE, Ralph S, Ray DW. Haplotype analysis of the polymorphic human vascular endothelial growth factor gene promoter. Cancer Res. 2003;63(4):812-6.

18. He Y, Ni J, Chen S, Jiang Y, Jia S, Gao Y. The vascular endothelial growth factor-2549 insertion/deletion polymorphism is not associated with susceptibility to hepatocellular carcinoma in Chinese. DNA Cell Biol. 2010;29(7):393-6. DOI: 10.1089/dna.2009.1015

19. Ropper AH1, Gorson KC, Gooch CL, Weinberg $\mathrm{DH}$, Pieczek A, Ware JH, et al. Vascular endothelial growth factor gene transfer for diabetic polyneuropathy: a randomized, double-blinded trial. Ann Neurol. 2009;65(4):386-93. DOI: 10.1002/ana.21675

20. Deguchi T, Hashiguchi T, Horinouchi S, Uto T, Oku 
H, Kimura K, et al. Serum VEGF increases in diabetic polyneuropathy, particularly in the neurologically active symptomatic stage. Diabetic Medicine. 2009;26(3):24752. DOI: 10.1111/j.1464-5491.2009.02680.x

21. Yang B, Cross DF, Ollerenshaw M, Millward BA, Demaine AG. Polymorphisms of the vascular endothelial growth factor and susceptibility to diabetic microvascular complications in patients with type 1 diabetes mellitus. J Diabetes Complications. 2003;17(1):1-6. DOI: $10.1016 / \mathrm{S} 1056-8727(02) 00181-2$
22. Kacso MI, Trifa PA, Popp AR, Bondor IC, Farcas FM, Lenghel RA, et al. Adiponectin gene $45 \mathrm{~T}>\mathrm{G}$ polymorphism is not associated to plasma adiponectin in a cohort of patients with type 2 diabetes from Romania. Rev Romana Med Lab. 2012;20(1):73-9.

23. Moldovan R, Kacsò I, Gherman-Căprioară M. Relationship between soluble intercellular adhesion molecule 1 and clinically manifest cardiovascular disease in diabetic chronic hemodialysis patients. Rev Romana Med Lab. 2012;20(4):353-61. 